\title{
Effects of dietary supplements on selected hematological and biochemical parameters of Pakistani athletes
}

\author{
Sarwat Jahan ${ }^{1}$, Andleeb Fatima', Iftikhar Alam², Asad Ullah', Humaira Rehman', Tayyaba Afsarr ${ }^{3}$ Ali Almajwal $^{2}$
} and Suhail Razak ${ }^{1,2^{*}}$

\begin{abstract}
Background: CDC's (Centers for Disease Control and Prevention) National Center for Health statistics recent reports have shown that an upsurge has occurred in the use of dietary supplements among age of 20 years since 1994 and this use shown regular increase. The purpose of our study was to investigate the effect of supplements on the reproductive health on male athletes in Pakistan.

Methods: A total of 150 adult male with mean age of $25.78 \pm 0.56$ years were included in this study and divided into four groups: Non-athlete control $(n=57)$, Non supplemental athlete control $(n=40)$, Supplemental athlete group I $(n=28)$ and supplemental athlete group II $(n=25)$. Blood $(10 \mathrm{ml})$ was taken from each subject. Complete blood count was performed and $5 \mathrm{ml}$ of blood was centrifuged to separate plasma and then analyzed for antioxidant enzyme (CAT, POD, GR and GSH) activities, Lipid peroxidation (TBARS), electrolyte, metal (sodium, potassium and zinc) and Luteinizing hormone $(\mathrm{LH})$ concentration.

Results: Complete blood count results showed normal RBC, WBC, Platelets, Hemoglobin, Hematocrit, Mean corpuscular hemoglobin and Mean corpuscular hemoglobin concentration. Antioxidant enzymes (CAT, POD, GR, GSH) increased significantly in supplemental athletes as compared to control groups. Sodium and potassium showed significant increase $(p<0.001)$ in supplemental athlete group I, while TBARS also showed significant increase $(p<0.05)$ in supplemental group I and II as compared to non athlete control while non supplemental athletes showed significant increase $(p<0.05)$ in TBARS concentration as compared to non athlete control. LH concentration was found to be decreased significantly $(p<0.05)$ in supplemental group I and II as compared to control groups.
\end{abstract}

Conclusion: It is therefore concluded from the present results that oxidative stress was considerably elevated in response to supplement consumption among athletes which may affect their health haematological parameters and reproductive hormones.

Keywords: Nutrition, Antioxidants, LH, Blood count

\section{Background}

Dietary supplement use in the general population is increasing day by day around the globe. An estimation of $30-50 \%$ increase has occurred in the rate of energy drinks and dietary supplements among adolescents in 2010 [1]. Young athletes have focused on different kind

\footnotetext{
* Correspondence: Ruhail12345@yahoo.com; ruhail12345@yahoo.com ${ }^{1}$ Reproductive Physiology Laboratory, Department of Animal Sciences, Quaid-i-Azam University, Islamabad, Pakistan

${ }^{2}$ Department of Community Health Sciences, College of Applied Medical Sciences, King Saud University, Riyadh, Kingdom of Saudi Arabia Full list of author information is available at the end of the article
}

of dietary supplements for quick results [2] which they consider secure and lawful [3].

The frequent use of these supplements is not good for health, studies have shown that continuous use of energy drinks and dietary supplements lead into neurological and cardiovascular problems [4-6].

Athletes are constrained from the use of diverse kinds of nutraceuticals which are habitually used for the treatment of different kind of complacencies as pain management [7], osteoarthritis [8, 9] and ulcerative colitis [10]. These nutraceuticals drugs are used by varoius companies

(c) The Author(s). 2018 Open Access This article is distributed under the terms of the Creative Commons Attribution 4.0 International License (http://creativecommons.org/licenses/by/4.0/), which permits unrestricted use, distribution, and 
in energy drinks and dietary supplements for swift effect, which does not require any pre- approval form Food and Drug administration (FDA) [11]. FDA does not confirm the quality control of manufactory process of ingredients found in the energy drinks and supplement like Ephedra, Caffeine, Amino Acids, L-tryptophan Phenylalanine, Branched Chain Amino Acids (BCAA), Vitamins and Minerals, Vitamin A, Vitamin B6, Niacin (nicotinic acid and nicotinamide) ginseng, multivitamins, taurine, and guarana [11-13]. Due to which Athletes are prone to severe health risks, like neurological, metabolic and cardiovascular problems [14-16].

Regardless of the availability of extensive information about supplement utilization from different parts of the world, limited data is accessible from Pakistan. However, even the limited number of studies shows relatively high use of supplement consumption among the Pakistani athletes. This elevated consumption may induce serious health consequences [17]. Numerous studies have also specified some adverse effects of dietary supplements usage, including cardiovascular, hematological, metabolic, and neurological problems [16] whereas, there is modest scientific data that confirms the advantageous effects of nutritional supplements in athletes [18]. Consequently, the sum of dietary supplement consumption should be constrained within the recommended dose [19]. Among the general populations, athletes are more predisposed to use these supplements as compared to other sportsmen. Nowadays, this idea has been raised in Pakistani youth and adolescent athletes. On the other hand, as the usage of supplements is more accepted by gym exercisers, serious measures should be taken about the effects of supplement consumption. Based on biochemical and physiological action of dietary supplements, this study was conducted for the purpose to assess the possible effects of some commonly used supplements by athletes on their hematological and biochemical parameters and then comparison was made with a control group.

\section{Methods}

\section{Study design and subjects}

The present study was conducted at Department of Animal Sciences, Faculty of Biological Sciences, Quaid-iAzam University and the Bio-gym Islamabad. Before onset of study, the purpose of study was verbally explained to all participants and they gave informed written consent showing their wiliness to participate in the study. The study was approved by ethical committee (BAS\#256) for research on human subject, Quaid-iAzam University, Islamabad. Male volunteer athletes who were not involved in any professional sports were selected for this study. A total of 150 adult males were included in this study. These included 93 athletes and 57 non-athletes (age: $25 \pm 8$ years; Range: $20-35$ years). All the volunteers were informed about all the procedures and outcomes of the study.

Prior to this study self-reported questionnaire was done form all the volunteers who participated in study. Personal, social, demographical and reproductive health questions were asked in the questionnaires.

The subjects were categorized into following four groups. Control athletes and non-athletes, and athletes who, in addition to exercise, voluntarily took supplements were categorized into 2 groups on the basis of type of supplements taken.

\section{Experimental design}

Control group I: Non athletes $(n=57)$

Control group II: Non-supplemental athlete group $(n=40)$

Supplemental athlete group (SAG) I*: $(n=28)$

Supplemental athlete group (SAG) II $¥:(n=25)$

*(SAG I) these athletes were taking supplement comprising human growth hormone $=4$ IU daily, dihydrotestosterone, $1000 \mathrm{mg} /$ week, Creatine $=40,000 \mathrm{mg}$ daily; Glutamine $=40,000 \mathrm{mg}$ daily; Branched chain amino acids $=200,000 \mathrm{mg}$ protein $/$ day.

¥ (SAG II) were taking supplements including dihydrotestosterone $=1000 \mathrm{mg} /$ week; cytomel 13liothyronine = $0.1 \mathrm{mg} /$ day; Clenbuterol $=0.02-0.1 \mathrm{mg} /$ day; Caffeine, ephedrine, aspirin $=150,000 \mathrm{mg} /$ day; L-arginine $=1500$ $3000 \mathrm{mg}$ twice $/$ day; L-carnitine $=500-1500 \mathrm{mg}$ twice $/$ day; Vanadyl sulfate $=50 \mathrm{mg}$ twice $/$ day; medium chain triglycerides $=50 \mathrm{mg}$ twice $/$ day.

\section{Age and body mass index (BMI)}

Age was self-reported. Weight and height were measured using the standard methods (Alam et al., 2013). BMI was calculated using weight and height and reference ranges were taken from World Health Organization defining underweight as $\mathrm{BMI}<18.50$; normal weight = 18.50-24.99; overweight $\geq 25.00$; and obese $\geq 30.00$.

\section{Blood collection and serum separation}

A blood sample $(10 \mathrm{ml})$ was anesthetically obtained from all the participants by a trained and certified technician. All the samples were centrifuged (kokusan, Japan), for $15 \mathrm{~min}$ at $3000 \mathrm{rpm}$ to separate plasma which was transferred to eppendorf tubes and stored at $-70{ }^{\circ} \mathrm{C}$ respectively until analyzed.

\section{Complete blood profile}

Five milliliters of blood from syringe was transferred into lavender vacutainer, containing Ethylenediaminetetraacetic acid (EDTA) as anticoagulant. Blood count was performed on an automated hematology analyzer (Medonic 
M16S, Sweden) at Life Care Diagnostic laboratory, Rawalpindi. Each count presented the data of white blood cell count (WBC), red blood count (RBC) platelets count (Plt), mean platelet volume (MPV), mean corpuscular volume $(\mathrm{MCV})$, measurement of hemoglobin $(\mathrm{Hgb})$, and measurement of hematocrit (Hct), red blood cell distribution width percentage (RDW \%), mean corpuscular hemoglobin $(\mathrm{MCH})$ and mean corpuscular hemoglobin concentration $(\mathrm{MCHC})$.

\section{Plasma analysis}

Plasma samples were analyzed for the determination of antioxidant enzymes activity of Catalase CAT) [20] Peroxidase (POD) [21] Glutathione Reductase (GR) [22], Reduced Glutathione (GSH) [23], lipid peroxidation (TBARS) [24] on a UV spectrophotometer (Agilent 8453) while total protein estimation was done by AMP Diagnostics reagent kit on chemistry analyzer and hormonal concentration was detected by Enzyme Immuno Assay test kit (Amgenix Inc., USA).

\section{Determination of electrolytes/metal in blood}

Electrolytes $\left(\mathrm{Na}^{+}\right.$and $\left.\mathrm{K}^{+}\right)$and Zinc in blood was determined by following the method of [25] and [26] with some modification. It involves the following steps.

\section{Acid digestion of serum samples}

Acid digestion was done according to the following steps.

Prior to the start of acid digestion all the apparatus was soaked with $10 \%$ Nitric acid for $24 \mathrm{~h}$ and then washed with $69 \%$ nitric acid. Before the process of digestion pre-digestion was done in which each sample of $0.5 \mathrm{ml}$ of blood was taken and $5 \mathrm{ml}$ of $69 \% \mathrm{HNO}_{3}$ was added in it until it became clear.

\section{Digestion}

Samples were digested manually by boiling the whole blood in $\mathrm{HNO}_{3}$ on a hot plate at $400{ }^{\circ} \mathrm{C}$ until half of the liquid evaporated.

\section{Filtration}

After digestion these samples were filtered through filter paper and the final volume of filtrate was made to $15 \mathrm{ml}$ by adding distilled water. Samples at this stage were ready for atomic absorption spectrometry.

\section{Atomic absorption spectrometry}

Prior to the start of atomic absorption spectrometry the following standard solutions were prepared.

Standard solution of each salt of 1000 ppm concentration was prepared by following formula.

$$
\frac{\text { Molecular weight of salt } x 0.1=\mathrm{x}}{\text { Molecular weight of sample }}
$$

$\mathrm{x}$ grams of salt were dissolved in $100 \mathrm{ml}$ of distilled water to make $1000 \mathrm{ppm}$ solution.

In order to calibrate the instrument, diluted solutions having concentration from $1 \mathrm{ppm}$ to $50 \mathrm{ppm}$ were used. The different calculations were made using the formula.

$$
\mathrm{C}_{1} \mathrm{~V}_{1=} \mathrm{C}_{2} \mathrm{~V}_{2}
$$

Where $C_{1}$ represent concentration and $V_{1}$ volume of stock solution of standard and $\mathrm{C}_{2}$ and $\mathrm{V}_{2}$ are the required concentration and volume respectively.

\section{Determination of metal concentration}

For detection of different metals by Fast Atomic Absorption Spectrometry (SAAS), different lamps specific for that particular metal were used. A series of standard elements under analysis were run. Each digested sample was subjected to Acetylene flame of atomic absorbance spectrometer (Varian AA240FS, USA) and concentration of microelements was noted. These concentrations were obtained in ppm and converted into $\mathrm{mg} / \mathrm{l}$ by using the following formula

$$
\begin{aligned}
& \text { Metal concentration }(\mathrm{mg} / \mathrm{l}) \\
& =\frac{\text { final volume of dilution } \mathrm{x} \text { metal concentration }(\mathrm{ppm})}{\text { Volume of sample }}
\end{aligned}
$$

\section{Determination of plasma Luteinizing hormone}

The kit contained antibody-coated microtitter plate coated with 96 wells, LH standard set, contains six vials (ready to use) 0, 5, 20 50, 100 and $200 \mathrm{mlU} / \mathrm{ml}$, Enzyme conjugate reagent $12 \mathrm{ml}$, Trimethylbenzidine (TMB) substrate one bottle (ready to use) $12 \mathrm{ml}$, stop solution one bottle (ready to use) $12 \mathrm{ml}, 50 \mathrm{X}$ wash buffer concentrate one bottle $15 \mathrm{ml}$.

\section{Principle}

This test is based on a solid phase ELISA. The assay system utilizes one anti-LH antibody for solid phase (microtiter wells) immobilization and another mouse monoclonal anti-LH antibody in the antibody-enzyme (horsereddish peroxidase) conjugate solution. The test sample is allowed to react simultaneously with the antibodies resulting in the $\mathrm{LH}$ molecules being sandwiched between the solid phase and enzyme-linked antibodies. Unbound LH and LH enzymes conjugate is washed off by washing buffer. Upon addition of substrate, the intensity of the color is inversely proportional to the concentration of $\mathrm{LH}$ in the sample; a standard curve is prepared relating color intensity to the concentration of the $\mathrm{LH}$. 
Table 1 Mean \pm SEM age (years) and body mass index $\left(\mathrm{kg} / \mathrm{m}^{2}\right)$ of control subjects and supplemental athletes

\begin{tabular}{lll}
\hline Group & Age (years) & BMI $\left(\mathrm{kg} / \mathrm{m}^{2}\right)$ \\
\hline NA control $(n=57)$ & $25.60 \pm 0.59$ & $23.15 \pm 0.44$ \\
NSA control $(n=40)$ & $25.17 \pm 0.86$ & $26.43 \pm 0.56$ \\
SA-I $(n=28)$ & $26.43 \pm 0.88$ & $26.84 \pm 0.72$ \\
SA-II $(n=25)$ & $25.96 \pm 1.07$ & $25.77 \pm 0.87$ \\
\hline
\end{tabular}

\section{Procedure}

The reagents provided with kit were gently mixed prior to the start of the experiment.

Desired number of wells were secured and 50ul of standard, control and specimen were dispensed into wells. 100ul of enzyme cognate was added and the samples were mixed and incubated at $37{ }^{\circ} \mathrm{C}$ for 60 mins. Washing was done of the plate 5 times with Elisa plate washer. TMB substrate 100ul was added in wells and again incubated for $20 \mathrm{~min}$ at $37{ }^{\circ} \mathrm{C}$. later on stop solution $100 \mathrm{ul}$ was added in order to stop the solution and the absorbance was read at $450 \mathrm{~nm}$ on Elisa Plate reader.

\section{Statistical analysis}

All data is presented as the mean \pm standard error of mean. Data of in vivo assays recorded was analyzed by one way ANOVA carried by computer software SPSS version 16.0. $p<0.05$ was considered significantly significant.

\section{Results}

\section{Age and body mass index (BMI)}

The mean age (years) and BMI $\left(\mathrm{kg} / \mathrm{m}^{2}\right)$ of NA control was $25.60 \pm 0.59$ and $23.15 \pm 0.44$, NSA control $25.17 \pm 0.86$ and $26.43 \pm 0.56$, SA-I $26.43 \pm 0.88$ and $26.84 \pm 0.72$ and SA-II was $25.96 \pm 1.07$ and $26.77 \pm 0.87$ as expressed in Table 1 .

\section{Complete blood profile}

No significant difference was found in WBC count, RBC count, $\mathrm{Hb}$ concentrations, Hematocrit percentage (Hct $\%), \mathrm{MCH}$ MPV levels in both groups of supplemental athletes in comparison to control subjects. Platelets count showed significant increase $(P<0.05)$ in NSA control and significant decrease $(p<0.05)$ in SA-I and SA-II as compared to NA control but all groups have platelet count well within the normal range. Mean MCV showed significant increase $(\mathrm{p}<0.05)$ in NSA control and SA-I as compared to NA control while no significant difference in SA-II, as compared to NA control. However $\mathrm{MCV}$ of all the groups is well within the normal range. Mean corpuscular hemoglobin concentration decreased significantly $(P<0.001)$ in NSA control and SA-I, SA-II as compared to subjects of NA control group. Red blood cell Distribution Width percentage (RDW \%) levels were significantly high $(p<0.05)$ in NSA control as compared to NA control while no significant difference was observed in SA-I and SA-II, in comparison with NA control group (Table 2).

\section{Antioxidant enzymes}

Catalase (CAT) activity was measured in all the four groups. CAT activity increased in non-supplement athletes and Supplemental athletes-I group as $(\mathrm{P}<0.001)$ compared to control. While there was no significant difference found in non-athletes and supplement athletes-II group (Table 3).

The levels of glutathione reductase were observed in all the groups and an increase in supplemental athletesII of $(P<0.0001)$ and decrease non-supplement athletes of $(\mathrm{P}<0.0001)$ were observed when compared to the non-athletes group (Table 3).

Table 2 Mean \pm SEM White blood cell count (WBC), Red blood cell count (RBC), hemoglobin count (HGH), hematocrit (HCT), Mean corpuscular volume (MCV), Mean corpuscular hemoglobin (MCH), Mean corpuscular hemoglobin concentration (MCHC) and platelet count (PLT) in control subjects and supplemental athletes

\begin{tabular}{|c|c|c|c|c|}
\hline & NA control $(n=57)$ & NSA control $(n=40)$ & SA-I $(n=28)$ & SA-II $(n=25)$ \\
\hline $\mathrm{RBC}\left(10^{12} / \mathrm{l}\right)$ & $5.10 \pm 0.11$ & $4.86 \pm 0.11$ & $4.99 \pm 0.12$ & $5.23 \pm 0.22$ \\
\hline WBC $\left(10^{9} / \mathrm{l}\right)$ & $7.99 \pm 0.69$ & $8.16 \pm 0.5$ & $9.84 \pm 0.8$ & $8.60 \pm 0.69$ \\
\hline $\operatorname{PLT}\left(10^{9} / I\right)$ & $235.78 \pm 7.62^{\mathrm{ab} \mathrm{b}^{* *}}$ & $256 \pm 12.63^{3^{* *}}$ & $188 \pm 17.31^{c^{* *}}$ & $200.88 \pm 11.49^{b c^{* *}}$ \\
\hline MPV (fl) & $10.08 \pm 0.21$ & $10.10 \pm 0.28$ & $10.78 \pm 0.48$ & $10.53 \pm 0.38$ \\
\hline $\mathrm{MCV}(\mathrm{fl})$ & $77.82 \pm 2.44^{\mathrm{ab} \mathrm{b}^{*}}$ & $88.47 \pm \pm^{a^{*}}$ & $86.49 \pm 1.25^{\mathrm{a}^{*}}$ & $83.21 \pm 1.96^{\mathrm{ab}^{*}}$ \\
\hline RDW (\%) & $14.34 \pm 0.38^{\mathrm{b}^{*}}$ & $16.63 \pm 0.79^{\mathrm{a}^{*}}$ & $14.46 \pm 0.21^{b^{*}}$ & $14.60 \pm 0.31^{b^{*}}$ \\
\hline $\mathrm{Hgb}(\mathrm{g} / \mathrm{dl})$ & $15.98 \pm 0.43$ & $15.83 \pm 0.25$ & $16.38 \pm 0.5$ & $16.05 \pm 0.53$ \\
\hline Hct (\%) & $39.54 \pm 0.95$ & $42.74 \pm 1.14$ & $43.35 \pm 1.57$ & $43.33 \pm 1.37$ \\
\hline $\mathrm{MCH}(\mathrm{pg})$ & $31.50 \pm 1.09$ & $32.75 \pm 0.66$ & $32.80 \pm 0.48$ & $30.85 \pm 0.91$ \\
\hline $\mathrm{MCHC}(\mathrm{g} / \mathrm{dl})$ & $40.46 \pm 0.25^{5^{* *}}$ & $37.31 \pm 0.84^{\mathrm{b}^{* *}}$ & $37.86 \pm 0.51^{b^{* *}}$ & $37.03 \pm 0.33^{\mathrm{b} * *^{*}}$ \\
\hline
\end{tabular}

Values are expressed as Mean \pm SEM. Different alphabets show that the values are significantly different while the same alphabets demonstrate that the values produce same result

${ }^{*}=p<0.05,{ }^{* *}=p<0.001,{ }^{* * *}=p<0.0001$

${ }^{a}$ Value vs NA control, ${ }^{b}$ Value vs NSA control, ${ }^{\circ}$ Value vs SA-1 
Table 3 Mean \pm SEM Plasma Catalase (CAT), Peroxidase (POD), Glutathione Reductase (GR) and Reduced Glutathione (GSH) activity in control subjects, supplemental athletes

\begin{tabular}{lllll}
\hline Group & CAT $(\mathrm{U} / \mathrm{min})$ & GR $(\mathrm{U} / \mathrm{l})$ & POD $(\mathrm{U} / \mathrm{min})$ & $\mathrm{GSH}(\mathrm{mM} /)$ \\
\hline NA control $(n=57)$ & $1.10 \pm 0.178^{\mathrm{b}^{* *}}$ & $24.13 \pm 2.15^{\mathrm{b}^{* * *}}$ & $13.43 \pm 1.28^{\mathrm{ab}^{*}}$ & $0.05 \pm 0.009$ \\
NSA control $(n=40)$ & $1.77 \pm 0.386^{\mathrm{ab}}$ & $15.83 \pm 1.36^{\mathrm{b}^{* * *}}$ & $10.24 \pm 1.3^{\mathrm{b}^{*}}$ & $0.09 \pm 0.018$ \\
SA-I $(n=28)$ & $2.32 \pm 0.278^{\mathrm{a}^{* *}}$ & $26.82 \pm 1.9^{\mathrm{b}^{* * *}}$ & $16.14 \pm 0.98^{\mathrm{a}^{*}}$ & $0.11 \pm 0.016$ \\
SA-II $(n=25)$ & $1.04 \pm 0.22^{\mathrm{b}^{* *}}$ & $42.39 \pm 6.0^{\mathrm{a}^{* * *}}$ & $15.05 \pm 1.09^{\mathrm{a}^{*}}$ & $0.38 \pm 0.324$
\end{tabular}

Values are expressed as Mean \pm SEM. Different alphabets show that the values are significantly different while the same alphabets demonstrate that the values produce same result

${ }^{*}=p<0.05,{ }^{* *}=p<0.001,{ }^{* * *}=p<0.0001$

${ }^{\mathrm{a}}$ Value vs NA control, ${ }^{\mathrm{b}}$ Value vs NSA control, ${ }^{\mathrm{c}}$ Value vs SA-1

In POD levels significant decrease of $(P<0.05)$ in supplemental athletes-I and in Supplemental athletes-II was observed when compared to the control groups.

In TBARS levels significant increase of $(P<0.05)$ was observed in non-supplemental athletes groups as compared to the non-athlete control group. While in the other groups no significant difference was observed as compared to control group.

There was no significant difference observed in GSH and protein levels when compared to the control groups (Tables 3 and 4).

\section{Electrolytes and metals}

Plasma sodium concentration was found significantly increased $(p<0.001)$ in SA-I as compared to control groups (Table 5). While significant increase in plasma Potassium concentration was observed in SA-I as compared to control groups (Table 5). However plasma Zinc levels showed no significant difference in any group in comparison with control. (Table 5).

\section{Plasma Luteinizing hormone (LH) concentration}

Plasma Luteinizing hormone concentration $(\mathrm{mIU} / \mathrm{ml})$ displayed significant decrease $(p<0.05)$ in SA-I $(3.48 \pm$ $0.86)$ and SA-II (4.68 \pm 1.07$)$ as compared to NA (7.21 \pm $0.77)$ and NSA $(7.56 \pm 1.25)$ control groups.

Table 4 Mean \pm SEM Total protein content and thiobarbituric acid reactive substance activity in plasma of control subjects, non supplemental and supplemental athletes

\begin{tabular}{lll}
\hline Group & Total protein $(\mathrm{g} / \mathrm{dl})$ & TBARS $(\mathrm{nM} / \mathrm{mg}$ protein) \\
\hline NA control $(n=57)$ & $6.74 \pm 0.22$ & $1.79 \mathrm{E}-08 \pm 5.22 \mathrm{E}-09^{c^{*}}$ \\
NSA control $(n=40)$ & $7.41 \pm 0.54$ & $6.35 \mathrm{E}-08 \pm 3.24 \mathrm{E}-09^{\mathrm{a}^{*}}$ \\
SA-I $(n=28)$ & $7.87 \pm 0.22$ & $3.84 \mathrm{E}-08 \pm 3.36 \mathrm{E}-09^{b^{*}}$ \\
SA-II $(n=25)$ & $7.47 \pm 0.19$ & $4.28 \mathrm{E}-08 \pm 5.26 \mathrm{E}-09^{b^{*}}$ \\
\hline
\end{tabular}

Values are expressed as Mean \pm SEM. Different alphabets $(a, b, c)$ show that the values are different while similar ones demonstrate values producing similar result

${ }^{*}=p<0.05,{ }^{* *}=p<0.001,{ }^{* * *}=p<0.000$

a Value vs NA control, ${ }^{b}$ Value vs NSA control, ' $V a l u e ~ v s ~ S A-1$

\section{Discussion}

Effect of Supplements on the exercise induce oxidative stress, inflammatory response and muscle damage have been shown by multiple mechanisms in the past. Present study was designed to show the effects of commonly used dietary supplements on reproductive health of Pakistani male athletes. The results showed that the body mass index $\left(\mathrm{kg} / \mathrm{m}^{2}\right)$ of non-supplemental control, non-supplemental athletes control, supplemental athletes I and II was $(23.15 \pm 0.44,26.43 \pm 0.56,26.84 \pm 0.72$ and $25.77 \pm 0.87)$ which is higher than the body mass index of athletes in WHO global database [27].

All the parameters of blood count were normal which are in accordance with the previous study which also reported normal blood count results in subjects using sport supplements [28].

Numerous studies have shown many health benefits of exercise, where some studies have also shown that exercise upsurges the oxygen uptake which induces oxidative stress, high level of reactive oxygen species (ROS) and free radicals in the body which at times lead into the breakdown of fatty acids, amino acids, proteins and DNA macromolecules [29-32]. Recent studies have shown that the initiators of two important redox-sensitive signaling pathways including nuclear factor $\mathrm{\kappa} B(\mathrm{NF}-\mathrm{kB})$ and mitogen activated protein kinase (MAPK) are due to ROS production during exercise [33].

Previous studies have reported increased antioxidant enzymes and antioxidant nutrients in response to extreme exercise [33-36]. Present study supports these findings as depicted by increased Catalase, Peroxidase, Glutathione reductase and TBARS levels in the plasma of athlete groups as compared to non-athlete controls. Reduced-glutathione (GSH) concentration also increased in NSA control, SA-I and SA-II as compared to NA control but the difference is not statistically significant.

In the present study, plasma Catalase activity of supplemental athlete group (SA-I) increased significantly $(p<$ 0.001) than both control groups. These findings also strengthen previous findings that Creatine supplementation did not inhibit rise in oxidative stress markers (Catalase, Glutathione peroxidase and Superoxide dismutase) which 
Table 5 Plasma Sodium, Potassium, Zinc and luteinizing hormone (LH) levels in control subjects and supplemental athletes. Different alphabets show that the values are significantly different while same alphabets show similar results

\begin{tabular}{lllll}
\hline Group & Sodium $(\mathrm{mg} / \mathrm{l})$ & Potassium $(\mathrm{mg} / \mathrm{l})$ & Zinc $(\mathrm{mg} / \mathrm{l})$ & $\mathrm{LH}(\mathrm{mlU} / \mathrm{ml}$ \\
\hline NA control $(n=57)$ & $3102.60 \pm 113.3^{\mathrm{b}^{* *}}$ & $298.98 \pm 26.4^{\mathrm{b}^{* *}}$ & $0.69 \pm 0.03$ & $7.2 \pm 0.77^{\mathrm{b}^{*}}$ \\
NSA control $(n=40)$ & $3136.08 \pm 96.6^{\mathrm{b}^{* *}}$ & $297.23 \pm 21.7^{\mathrm{b}^{* *}}$ & $0.88 \pm 0.17$ & $7.56 \pm 1.25^{\mathrm{b}^{*}}$ \\
SA-I $(n=28)$ & $4010.49 \pm 159.6^{\mathrm{a}^{* *}}$ & $798.67 \pm 46^{\mathrm{a}^{* *}}$ & $0.69 \pm 0.07$ & $3.48 \pm 0.86^{\mathrm{b}^{*}}$ \\
SA-II $(n=25)$ & $3236.93 \pm 90.94^{\mathrm{b}^{* *}}$ & $390.99 \pm 15^{\mathrm{b}^{* *}}$ & $0.56 \pm 0.03$ & $4.68 \pm 1.07^{\mathrm{b}^{*}}$ \\
\hline
\end{tabular}

Values are expressed as Mean \pm SEM. Different alphabets show that the values are significantly different while the same alphabets demonstrate that the values produce same result

${ }^{*}=p<0.05,{ }^{* *}=p<0.001,{ }^{* * *}=p<0.0001$

a Value vs NA control, ${ }^{b}$ Value vs NSA control

rise due to exercise. Lawler et al., (2002) for the first time reported antioxidant activity of creatine. However, few reports suggested that Creatine supplementation in diseased populations, has been effective in reducing oxidative stress $[34,37,38]$ There was no significant increase in second supplemental athlete group (SA-II) in plasma Catalase activity as compared to both the control goups, and it remained similar to non-athletes control (NA control). This Catalase suppression may be due to Vanadyl sulfate supplementation, as a previous study reported that Vanadyl sulfate administration to diabetic rats significantly decreased serum antioxidant enzyme levels, which were significantly raised by diabetes in muscle tissues.

Davies et al., (1987) measured lipid peroxidation in male Long Evans rats that exercise, increased lipid peroxidation as measured by TBARS assay. While many studies have supported Davies' findings [39-41], as many have refuted them [42, 43]. The present study is also in agreement with Davies' findings that exercise induces oxidative stress as indicated by the significantly increased levels of TBARS in non-supplemental athlete group (NSA control) and in both the supplemental athlete groups as compared to non-athlete control. (NA control); however in the supplemental groups (SA-I and SA-II) which along with other supplements also consumed Creatine (SA-I) and vanadyl sulfate (SA-II), the increase in TBARS concentration is slightly suppressed.

In present study, an increase in the plasma electrolyte was seen in athletes who used supplements as compared to those who do not use supplements like control group which is in relation to the previous studies [44-47] where Creatine supplementation causes electrolyte disturbances and renal damages.

Studies revealed that trace elements are also important in the enhancement of performance. Deficiency of Zinc in the body of athletes can lead to weight loss, fatigue and osteoporosis [48]. In our study, we observed normal Zinc levels in athletes who were using dietary supplements.

This study also investigated the effect of sports supplements on Luteinizing hormone level which was found to be significantly decreased in both the supplemental groups as compared to control groups. This indicates an inhibitory effect on the pituitary level. This inhibition in LH production may consequently lead to low Testosterone production and thus reproduction may be affected. However, this might be the effect of negative feedback of steroids (dihydrotestosterone) taken by the athletes. These results are in accordance with previous study in which men uses different type of supplements exhibit persistently reduced endogenous testosterone concentrations [49].

\section{Conclusion}

Dietary supplements intake for a long period have been observed to have direct effect on health of athletes. The indiscriminate use of dietary supplements on a "just-in-case basis" is to be discouraged, and is likely to do more harm than good. For the safety of athletes dietary supplements where nutrient needs can be met by normal food shall be avoided and athletic coaches and trainers shall be educated in using natural food to meet the desired results. Supplements such as steroids and other ergogenic substances shall not be used by the athletes expect where medically indicated and where use is monitored by experts in the field.

\section{Abbreviation}

BCAA: Branched Chain Amino Acids; CAT: Catalase; CDC: Centers for Disease Control; EDTA: Ethylenediaminetetraacetic acid; FAD: Flavin adenine dinucleotide; GR: Glutathione Reductase; GSH: Reduced Glutathione; LH: Luteinizing hormone; MAPK: Mitogen-activated protein kinase; NFkb: Nuclear factor kappa-light-chain-enhancer of activated B cells; POD: Peroxidase; ROS: Reactive oxygen species; SOD: Superoxide dismutase; TMB: Trimethylbenzidine; WBC: White blood cell

\section{Acknowledgements}

We are thankful to the Department of Animal Sciences, Quaid-i-Azam University, Islambad, Pakistan. We are grateful to the Deanship of Scientific Research at King Saud University for its support of this research through Research Group Project number 193.

\section{Funding}

The project was partially funded by the Higher Education Commission (HEC) of Pakistan. We are grateful to the Deanship of Scientific Research at King Saud University for its funding of this research through Research Group Project number 193 in designing, sample collection and data interpretition.

Availability of data and materials

The datasets used and/or analyzed during the current study are available from the corresponding author on reasonable request.

\section{Authors' contributions}

SJ designed the study, conceived the study and analyzed the results. AF and

$\mathrm{AU}$ conceived an initial part of the study, performed the experiment and 
helped in compiling the results. SR helped in writing the results. SJ, SR, HR, IA and TA wrote the paper with input from all other authors SR, TA, IA and AA made substantial contribution in interpretation of data and revising the manuscript for intellectual content. All authors read and approved the final manuscript.

\section{Ethics approval and consent to participate}

This study makes use of Humans and the experimental protocol was approved (BAS\#0256) by the ethical board of Quaid-i-Azam University, Islamabad Pakistan. Before onset of study, the purpose of study was verbally explained to all participants and they gave informed written consent showing their wiliness to participate in the study.

\section{Consent for publication}

Not applicable.

\section{Competing interests}

The authors declare that they have no competing interests.

\section{Publisher's Note}

Springer Nature remains neutral with regard to jurisdictional claims in published maps and institutional affiliations.

\section{Author details}

${ }^{1}$ Reproductive Physiology Laboratory, Department of Animal Sciences, Quaid-i-Azam University, Islamabad, Pakistan. ${ }^{2}$ Department of Community Health Sciences, College of Applied Medical Sciences, King Saud University, Riyadh, Kingdom of Saudi Arabia. ${ }^{3}$ Department of Biochemistry,

Quaid-i-Azam university, Islamabad, Pakistan.

\section{Received: 28 January 2018 Accepted: 28 September 2018} Published online: 13 December 2018

\section{References}

1. Seifert SM, Schaechter JL, Hershorin ER, Lipshultz SE. Health effects of energy drinks on children, adolescents, and young adults. Pediatrics. 2011; 127(3):511-28.

2. Darvishi L, Askari G, Hariri M, Bahreynian M, Ghiasvand R, Ehsani S, et al. The use of nutritional supplements among male collegiate athletes. Int J Prev Med. 2013;4(Suppl 1):S68.

3. Williams MH. Dietary supplements and sports performance: introduction and vitamins. J Int Soc Sports Nutr. 2004;1(2):1

4. Bagwath Persad L. Energy drinks and the neurophysiological impact of caffeine. Front Neurosci. 2011:5:116

5. Rottlaender D, Motloch L, Reda S, Larbig R, Hoppe U. Cardiac arrest due to long QT syndrome associated with excessive consumption of energy drinks. Int J Cardiol. 2012;158(3):e51-e2.

6. Steinke L, Kalus JS, Dhanapal V, Lanfear DE, Berlie HD. "Energy drink" consumption causes increases in blood pressure and heart rate. Circulation. 2007;116(Suppl 16):II_831.

7. Curatolo M, Bogduk N. Pharmacologic pain treatment of musculoskeletal disorders: current perspectives and future prospects. Clin J Pain. 2001;17(1):25-32.

8. Mautone G. Efficacy of glucosamine and chondroitin for treatment of osteoarthritis. JAMA. 2000;284(10):1241.

9. McAlindon TLM, Gulin J, Felson D. Glucosamine and chondroitin for treatment of osteoarthritis. A systematic quality assessment and metaanalysis. JAMA. 2000;284:1469-75.

10. Kanauchi O, Iwanaga T, Mitsuyama K. Germinated barley foodstuff feeding Digestion. 2001;63(Suppl. 1):60-7.

11. Hoyte CO, Albert D, Heard KJ. The use of energy drinks, dietary supplements, and prescription medications by United States college students to enhance athletic performance. J Community Health. 2013;38(3):575-80.

12. Jacobs I, Pasternak H, Bell DG. Effects of ephedrine, caffeine, and their combination on muscular endurance. Med Sci Sports Exerc. 2003:35(6):987-94.

13. Schwenk TL, Costley CD. When food becomes a drug: nonanabolic nutritional supplement use in athletes. Am J Sports Med. 2002;30(6):907-16.

14. Scally MC, Hodge A. A report of hypothyroidism induced by an overthecounter fat loss supplement (Tiratricol). Int J Sport Nutr Exerc Metab. 2003;13:112-6

15. Foxford RJ, Sahlas DJ, Wingfield KA. Vasospasm-induced stroke in a varsity athlete secondary to ephedrine ingestion. Clin J Sport Med. 2003;13(3):183-5.
16. Palmer ME, Haller C, McKinney PE, Klein-Schwartz W, Tschirgi A, Smolinske SC, et al. Adverse events associated with dietary supplements: an observational study. Lancet. 2003;361(9352):101-6.

17. Schroder H, Navarro E, Mora J, Seco J, Torregrosa J, Tramullas A. The type, amount, frequency and timing of dietary supplement use by elite players in the first Spanish basketball league. J Sports Sci. 2002;20(4):353-8.

18. Geyer H, Parr M, Mareck U, Reinhart U, Schrader $Y$, Schänzer W. Analysis of non-hormonal nutritional supplements for anabolicandrogenic steroids-results of an international study. Int J Sports Med. 2004:25(02):124-9.

19. Dawson WJ. American College of Sports Medicine, American dietetic association, and dietitians of Canada: nutrition and athletic performance (joint position statement). Med Probl Perform Art. 2002;17(1):51-3.

20. AEBI H, Wyss SR, Scherz B, Skvaril F. Heterogeneity of erythrocyte catalase II. FEBS J. 1974:48(1):137-45.

21. Carlberg I, Mannervik B. Purification and characterization of the flavoenzyme glutathione reductase from rat liver. J Biol Chem. 1975;250(14):5475-80.

22. Goldberg D, Spooner R. VerlogChemie, vol. 3. Deerfield Beach: FI. V; 1983. p. 258-65.

23. Burtis CA, Ashwood ER. Tietz textbook of clinical chemistry. 1999.

24. Iabal M, Sharma S, Rezazadeh H, Hasan N, Abdulla M, Athar M. Glutathione metabolizing enzymes and oxidative stress in ferric nitrilotriacetate mediated hepatic injury. Redox Rep. 1996;2(6):385-91.

25. Teresa M, Vasconcelos S, Tavares HM. Trace element concentrations in blood and hair of young apprentices of a technical-professional school. Sci Total Environ. 1997:205(2):189-99.

26. Tripathi $R$, Raghunath $R$, Mahapatra S, Sadasivan S. Blood lead and its effect on cd, cu, Zn, Fe and hemoglobin levels of children. Sci Total Environ. 2001;277(1):161-8.

27. Ode JJ, Pivarnik JM, Reeves MJ, Knous JL. Body mass index as a predictor of percent fat in college athletes and nonathletes. Med Sci Sports Exerc. 2007:39(3):403-9.

28. Timcheh-Hariri A, Balali-Mood M, Aryan E, Sadeghi M, Riahi-Zanjani B. Toxic hepatitis in a group of 20 male body-builders taking dietary supplements. Food Chem Toxicol. 2012;50(10):3826-32.

29. Yavari A, Javadi M, Mirmiran P, Bahadoran Z. Exercise-induced oxidative stress and dietary antioxidants. Asian J Sports Med. 2015;6(1):e24898.

30. Kelkar G, Subhadra K, Chengappa RK. Effect of antioxidant supplementation on hematological parameters, oxidative stress and performance of Indian athletes. J Hum Ecol. 2008;24(3):209-13.

31. Peake J, Suzuki K. Neutrophil activation, antioxidant supplements and exercise-induced oxidative stress. Exerc Immunol Rev. 2004;10(1):129-41.

32. Lambertucci RH, Levada-Pires AC, Rossoni LV, Curi R, Pithon-Curi TC. Effects of aerobic exercise training on antioxidant enzyme activities and mRNA levels in soleus muscle from young and aged rats. Mech Ageing Dev. 2007;128(3):267-75.

33. Ji LL. Antioxidant signaling in skeletal muscle: a brief review. Exp Gerontol. 2007:42(7):582-93.

34. Belviranlı M, Gökbel H. Acute exercise induced oxidative stress and antioxidant changes. Eur J Gen Med. 2006;3(3):126-31.

35. Elokda AS, Nielsen DH. Effects of exercise training on the glutathione antioxidant system. Eur J Cardiovasc Prev Rehabil. 2007;14(5):630-7.

36. Terblanche $\mathrm{S}$. The effects of exhaustive exercise on the activity levels of catalase in various tissues of male and female rats. Cell Biol Int. 1999; 23(11):749-53.

37. Rodriguez MC, MacDonald JR, Mahoney DJ, Parise G, Beal MF, Tarnopolsky MA. Beneficial effects of creatine, CoQ10, and lipoic acid in mitochondrial disorders. Muscle Nerve. 2007;35(2):235-42.

38. Tarnopolsky MA, Simon DK, Roy BD, Chorneyko K, Lowther SA, Johns DR, et al. Attenuation of free radical production and paracrystalline inclusions by creatine supplementation in a patient with a novel cytochrome b mutation. Muscle Nerve. 2004;29(4):537-47.

39. Johnson BD, Padilla J, Wallace JP. The exercise dose affects oxidative stress and brachial artery flow-mediated dilation in trained men. Eur J Appl Physiol. 2012;112(1):33-42.

40. Mastaloudis A, Leonard SW, Traber MG. Oxidative stress in athletes during extreme endurance exercise. Free Radic Biol Med. 2001;31(7):911-22.

41. Davies KJ, Quintanilha AT, Brooks GA, Packer L. Free radicals and tissue damage produced by exercise. Biochem Biophys Res Commun. 1982;107(4):1198-205.

42. Inayama T, Kumagai Y, Sakane M, Saito M, Matsuda M. Plasma proteinbound sulfhydryl group oxidation in humans following a full marathon race. Life Sci. 1996;59(7):573-8. 
43. Kamber MBN, Saugy M, Rivier L. Nutritional supplements as a source for positive doping cases? Int I Sport Nutr Exerc Metab. 2001;11:258-63.

44. Pecci M, Lombardo J. Performance-enhancing supplements. Phys Med Rehabil Clin N Am. 2000;11(4):949-60.

45. Persky AM, Brazeau GA, Hochhaus G. Pharmacokinetics of the dietary supplement creatine. Clin Pharmacokinet. 2003;42(6):557-74.

46. Poortmans JR, Francaux M. Adverse effects of creatine supplementation. Sports Med. 2000;30(3):155-70.

47. Catlin DH, Leder BZ, Ahrens B, Starcevic B, Hatton CK, Green GA, et al. Trace contamination of over-the-counter androstenedione and positive urine test results for a nandrolone metabolite. JAMA. 2000;284(20):2618-21.

48. Micheletti A, Rossi R, Rufini S. Zinc status in athletes. Sports Med. 2001; 31(8):577-82.

49. Calfee R, Fadale P. Popular ergogenic drugs and supplements in young athletes. Pediatrics. 2006;117(3):e577-e89.

Ready to submit your research? Choose BMC and benefit from:

- fast, convenient online submission

- thorough peer review by experienced researchers in your field

- rapid publication on acceptance

- support for research data, including large and complex data types

- gold Open Access which fosters wider collaboration and increased citations

- maximum visibility for your research: over $100 \mathrm{M}$ website views per year

At $\mathrm{BMC}$, research is always in progress.

Learn more biomedcentral.com/submissions 